\title{
Leaf Nutrient Resorption and Export Fluxes of Avicennia marina in the Central Red Sea Area
}

OPEN ACCESS

Edited by:

Christos Dimitrios Arvanitidis, Hellenic Centre for Marine Research,

Greece

Reviewed by:

Paolo Magni,

Consiglio Nazionale Delle Ricerche

(CNR), Italy

Martin Zimmer

Leibniz Centre for Tropical Marine Research (LG), Germany

B. Mohan Kumar

Nalanda University, India

*Correspondence:

Hanan Almahasheer

halmahasheer@iau.edu.sa

${ }^{\dagger}$ Present Address:

Xabier Irigoien,

AZTI - Marine Research, Herrera Kaia

Portualdea z/g - 20110 Pasaia

(Gipuzkoa), Spain

IKERBASQUE, Basque Foundation for Science, Bilbao, Spain

Specialty section:

This article was submitted to Marine Ecosystem Ecology, a section of the journal Frontiers in Marine Science

Received: 06 September 2017 Accepted: 25 May 2018 Published: 13 June 2018

Citation:

Almahasheer $\mathrm{H}$, Duarte CM and Irigoien X (2018) Leaf Nutrient Resorption and Export Fluxes of Avicennia marina in the Central Red Sea Area. Front. Mar. Sci. 5:204. doi: 10.3389/fmars.2018.00204

\author{
Hanan Almahasheer ${ }^{1 *}$, Carlos M. Duarte ${ }^{2}$ and Xabier Irigoien ${ }^{2 \dagger}$ \\ ${ }^{1}$ Department of Biology, College of Science, Imam Abdulrahman Bin Faisal University (IAU), Dammam, Saudi Arabia, ${ }^{2}$ Red \\ Sea Research Center, King Abdullah University of Science and Technology, Jeddah, Saudi Arabia
}

Red Sea mangroves occur in an oligotrophic sea without permanent freshwater inputs. Understanding the mechanisms to cope with nutrient limitation is, therefore, important to understand their distribution and nutrient dynamics in coastal ecosystems. We measured total number of meristems to estimate their leaves production and nutrients $(N, P$, and $\mathrm{Fe}$ ) as a function of age in Avicennia marina leaves. Then estimated resorption rates; the recovery of nutrients from senescing leaves before they are shed in a total of 91 leaf from four different mangroves stands in the Central Red Sea. We found that the concentration of $\mathrm{N}$ and $\mathrm{P}$ but not Fe declined with age. Nutrient content also declined in the older leaves with high resorption capacity of 69 and $72 \%$ in $N$ and $P$ vs. low resorption of $42 \%$ in Fe. The role of Fe resorption is poorly studied in plants, nevertheless, this study could provide an insight into our knowledge of iron resorption in the mangroves, which has never been assessed before. The leaf nutrient export flux from senescing leaves in monospecific stand of Avicennia marina was 9, 0.4 and $1 \mathrm{~g} \mathrm{~m}^{-2}$ year ${ }^{-1}$ for $\mathrm{N}, \mathrm{P}$, and Fe respectively, suggesting mangrove litter-fall to be an important source of bioavailable iron in particular, due to its low resorption, to the adjacent oligotrophic ecosystem.

Keywords: leaves, nitrogen, phosphorous, iron, limitation, retention, mangroves, coastal ecosystem

\section{INTRODUCTION}

Nutrient resorption, the recovery of nutrients from senescing leaves before they are shed, is a key internal strategy allowing plants to avoid losing nutrients (Aerts and Chapin, 1999). The withdrawal of nutrients from senescing leaves allows plants to reuse them again (Aerts and Chapin, 1999) to reproduce structures and new leaves (Chapin and Van Cleve, 2000; Ochieng and Erftemeijer, 2002). And to conserve nutrients to consequently, influences different processes as competition, nutrient uptake, and productivity (Killingbeck, 1996). Also, at the ecosystem level, nutrient resorption influences nutrient cycling (Aerts and Chapin, 1999).

Nutrient limitation is prevalent among plant communities, including mangroves e.g. (Koch and Snedaker, 1997). Mangroves have different strategies to cope with nutrient limitation, including shifts in biomass allocation, such as increasing root biomass in mangrove seedlings when the nutrients or light are low (McKee, 1995) or, conversely, enhancing the growth rate of shoots compared to roots in response to nutrient enrichment (Lovelock et al., 2009). Ultimately, nutrient limitation (Naidoo, 2009), and other factors result in mangrove dwarfing.

Nutrient limitation in mangrove seedlings and trees has generally been studied in terms of nitrogen and phosphorus limitation (Boto and Wellington, 1983; Naidoo, 1987, 2009; Feller, 1995; 
Koch and Snedaker, 1997; Feller et al., 1999, 2003a,b; Lovelock et al., 2004, 2006, 2007; Alongi, 2011). Additionally, iron has also been found to be limiting (Alongi, 2010; Almahasheer et al., 2016b), and it has been suggested that the low availability of the three elements may be the reason for mangroves absence in several coastlines otherwise having conditions suitable for mangrove growth (Sato et al., 2011). Nutrient resorption may be, therefore, a key strategy for mangroves to grow in oligotrophic environments, such as the Red Sea (Almahasheer et al., 2016b).

Resorption may occur throughout a leaf's life, especially as leaves become increasingly shaded (Wright and Westoby, 2003), however, sun leaves and shade leaves did not affect nutrient resorption efficiency in some evergreen plant whereas the location did (DOGAN et al., 2015). Resorption mechanisms have been extensively studied in terrestrial and aquatic ecosystems (see reviews in Killingbeck (1996) and Hemminga et al. (1999). Resorption values usually ranged from 50 to $90 \%$ of $\mathrm{N}$ and $\mathrm{P}$ from different plant species (Aerts and Chapin, 1999).

Moreover, $\mathrm{N}$ resorption reported in different mangrove species in Kenya ranging from 53 to 69\% (Rao et al., 1994), similarly, a review by Reef et al. (2010) reported resorption values in different mangrove species around the world with $\mathrm{N}$ resorption ranging from $<5$ to $69 \%$. And up to $72 \%$ for $\mathrm{P}$ resorption by Alongi (2002), also P resorption has been reported for a number of Avicennia marina stands (Rao et al., 1994; Ochieng and Erftemeijer, 2002; Alongi et al., 2005; Lovelock et al., 2007, 2010, 2011; Zhou et al., 2010; Wei et al., 2015). Additionally, iron resorption in mangroves has not been assessed

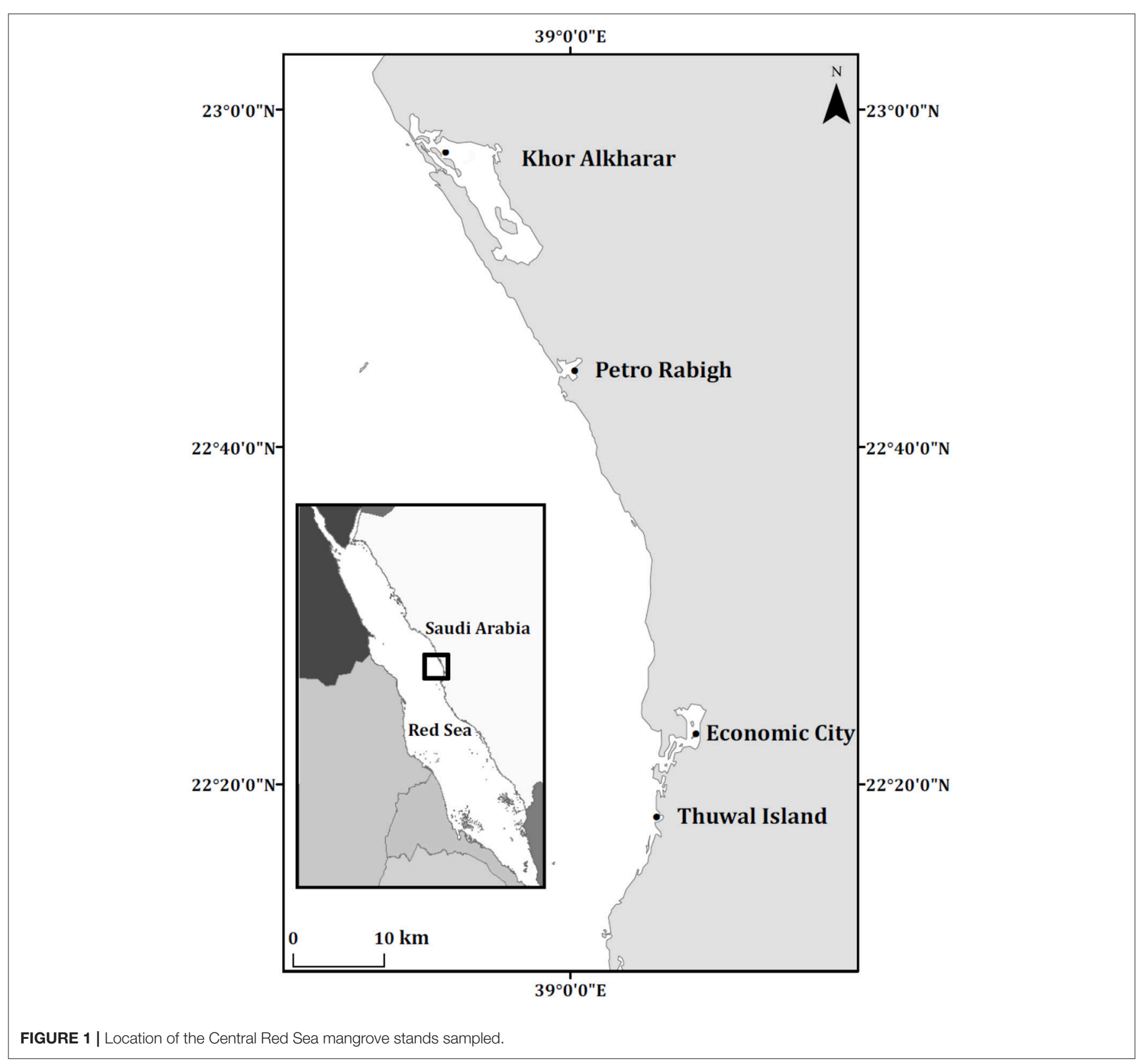


as yet. Moreover, mangroves play an important role in the biogeochemical cycle as a source of nutrients to costal ecosystems (Hussain and Badola, 2008), yet the amount is linked to the hydrology of mangrove forests and varies among the different types of mangroves (Twilley and Day, 1999). For e.g. the export of biomass and nutrients from the Matang Mangroves through leaf litter alone was around 3.9 and 0.1 tons $\mathrm{ha}^{-1}$ year $^{-1}$ respectively (Gong and Ong, 1990), whereas, mangrove leaf nutrient export flux from the Red Sea remains unknown.

Here we examine the rate of leaf nutrient resorption and the loss of nutrients involved with leaf shedding in Avicennia marina growing in the oligotrophic Red Sea. By comparing resorption values of Avicennia in the Red Sea to results reported for Avicennia stands elsewhere when possible. Finally, we determine the amount of nutrients export flux per $\mathrm{m}^{-2}$ year ${ }^{-1}$ supplied by falling senescing leaves of Avicennia marina in the central Red Sea and their stoichiometric ratios.

\section{MATERIALS AND METHODS}

\section{Study Area}

The Red Sea ranks amongst the most oligotrophic seas due to lack of river runoff and low nutrient supply (Mandura, 1997), and mangrove trees have been shown to be strongly nutrient limited, particularly by iron, in the Central Red Sea (Almahasheer et al., 2016b). Mangroves in the Central Red Sea develop as dwarf trees $(<2 \mathrm{~m}$ height) along a narrow belt. The Central Red Sea is the most oligotrophic part of the basin indicative of low Chl a concentrations Sea (Raitsos et al., 2013). And the low nutrient concentration could be due to the absence of riverine inputs and limited exchange with Indian ocean (Thompson et al., 2013). Avicennia marina in the Central Red Sea is subjected to extreme arid condition with salinity above $38 \mathrm{psu}$ and water temperature as high as $35^{\circ} \mathrm{C}$ (Almahasheer et al., 2016c). This study was conducted in ten trees within four different locations in the Central Red Sea. Mangrove locations were composed of monospecific stands of Avicennia marina, away from human disturbances in Khor Alkharar $\left(22^{\circ} 58^{\prime} 14.81^{\prime \prime} \mathrm{N} 38^{\circ} 50^{\prime} 44.27^{\prime \prime} \mathrm{E}\right)$, and close to petrochemical activities in Petro Rabigh $\left(22^{\circ} 45^{\prime} 5.81^{\prime \prime} \mathrm{N} 39^{\circ} 0^{\prime} 46.90^{\prime \prime} \mathrm{E}\right)$, while those at Economic City lagoon $\left(22^{\circ} 23^{\prime} 31.10^{\prime \prime} \mathrm{N} 39^{\circ} 7^{\prime} 49.07^{\prime \prime} \mathrm{E}\right)$ are under development. Those at Thuwal Island $\left(22^{\circ} 16^{\prime} 54.42^{\prime \prime} \mathrm{N} 39^{\circ}\right.$ $\left.5^{\prime} 6.12^{\prime \prime} \mathrm{E}\right)$ are less impacted by human activities $\left(22^{\circ} 16^{\prime} 54.42^{\prime \prime} \mathrm{N}\right.$ $39^{\circ} 5^{\prime} 6.12^{\prime \prime} \mathrm{E}$, Figure 1). Additional information about the study locations and their environmental conditions are described in (Almahasheer et al., 2016b,c).

\section{Sampling Leaves and Sediment in Mangrove Stands}

Leaves and sediment cores were collected in 2014 and 2015 from each location. A total of two to three long axillary branches in

TABLE 1 | Mean \pm SE (median) for the Avicenna marina girth, total number of meristems produced, tree density and leaves production in from two different locations in the Central Red Sea.

\begin{tabular}{|c|c|c|c|}
\hline Location & $\begin{array}{l}\text { Khor } \\
\text { Alkharar }\end{array}$ & $\begin{array}{l}\text { Thuwal } \\
\text { Island }\end{array}$ & $\begin{array}{l}\text { Average for } \\
\text { Central Red Sea }\end{array}$ \\
\hline No. Trees & 74 & 153 & 227 \\
\hline Tree density $\mathrm{m}^{-2}$ & 4.9 & 3.4 & 3.8 \\
\hline Girth (cm) & $\begin{array}{l}9.8 \pm 1.7 \\
(6.9)\end{array}$ & $\begin{array}{l}5.4 \pm 0.5 \\
(4)\end{array}$ & $\begin{array}{l}6.9 \pm 0.7 \\
(4.5)\end{array}$ \\
\hline $\begin{array}{l}\text { Number of meristems } \\
\text { plant }-1\end{array}$ & $\begin{array}{l}83.5 \pm 16.7 \\
(33.6)\end{array}$ & $\begin{array}{l}111.1 \pm 18 \\
(35.4)\end{array}$ & $\begin{array}{l}102.1 \pm 13.3 \\
(35.4)\end{array}$ \\
\hline $\begin{array}{l}\text { Nodes production } \\
\text { (node year }^{-1} \text { ) } \\
\text { (Almahasheer et al., } \\
\text { 2016c) }\end{array}$ & 9.56 & 9.72 & 9.59 \\
\hline 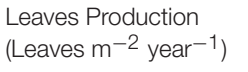 & $7,871.5$ & $7,345.2$ & 7,608 \\
\hline
\end{tabular}

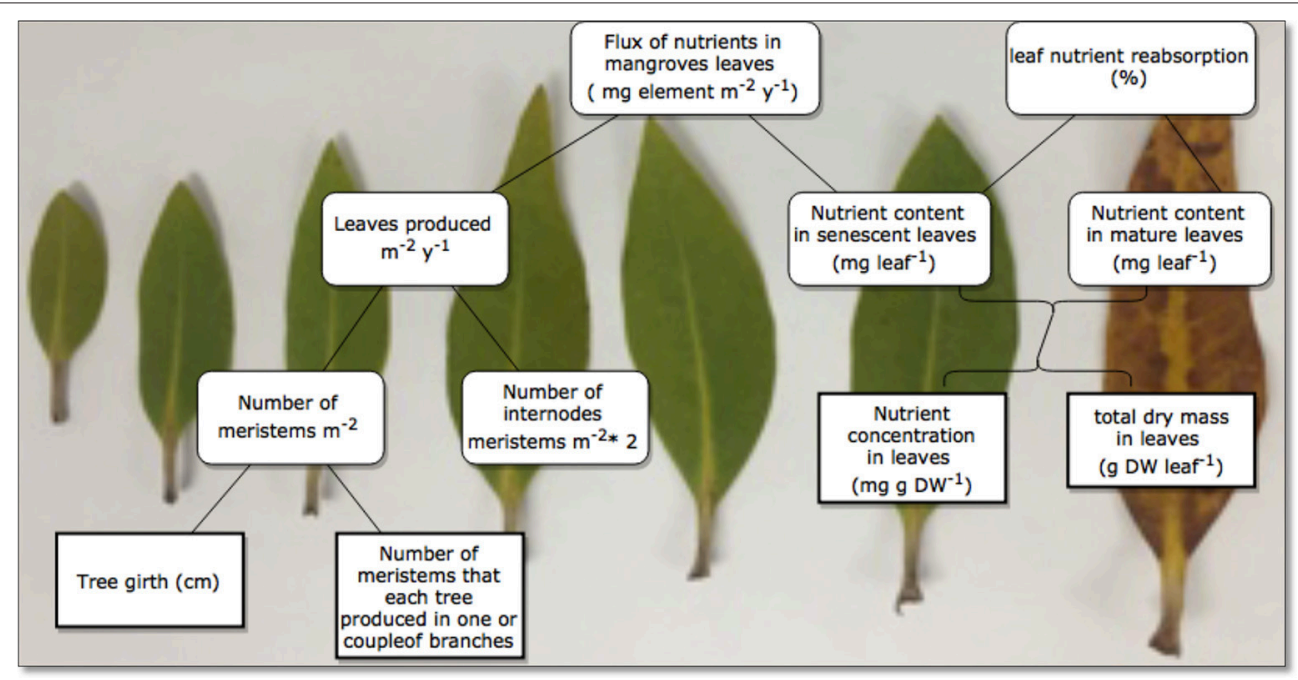

FIGURE 2 | Diagram of calculations used to estimate leaf export flux (mg element $\mathrm{m}^{-2}$ year ${ }^{-1}$ ) and leaf nutrient resorption (\%). 
each location were randomly selected, to collect a total of 91 leaves from 10 trees. The collected leaves were gently washed with sea water and numbered in the field based on their location in nodes along the axillary shoot starting from the first leaf near the meristem to the last attached senescing leaf. Sediments were sampled from the same locations using $170 \mathrm{~cm}$ long PVC cores, with a total of 26 sediment core ( 6 cores at Khor Alkharar, 4 cores at Petro Rabigh, 8 cores at Economic City and 8 cores at Thuwal Island). Sediments cores were sliced into $1 \mathrm{~cm}$ or $3 \mathrm{~cm}$ slices down to (24-27 cm compressed, which is equivalent to 26$45 \mathrm{~cm}$ decompressed), depending on the core-type (Almahasheer et al., 2017). The slices were dried in the oven at $60^{\circ} \mathrm{C}$ to constant weight, after measuring their fresh volume to calculate bulk density. The sediments were then subsampled for chemical analyses ( $\mathrm{C}, \mathrm{N}, \mathrm{P}$, and $\mathrm{Fe}$ ). Then to allow direct comparisons among locations, nutrient stocks in sediment samples at depth (26-45 cm decompressed) were standardized to $30 \mathrm{~cm}$.

\section{Laboratory Procedures}

Each leaf sampled was individually photographed, dried at $60^{\circ} \mathrm{C}$ till constant weight, then each leaf was weighted before grinding with a mortar. We then weighted approximately $2 \mathrm{mg}$ of each powdered leaf to the nearest $0.001 \mathrm{mg}$ with an ultramicro balance in a pre-combusted aluminum capsule, which was then used to determine the concentration of $\mathrm{C}$ and $\mathrm{N}$ on a FLASH 2000 CHNS Analyzer (Zimmermann et al., 1997). For $\mathrm{C}$ and $\mathrm{N}$ analyses in the sediment, $1 \mathrm{~g}$ of dried ground samples was acidified with $1 \mathrm{M} \mathrm{HCl}$ to remove inorganic carbon, centrifuged $(3,500 \mathrm{RPM} ; 5 \mathrm{~min})$ and the supernatant with acid residues was removed using a pipette, then washed in deionized water once, the residues were centrifuged again and the supernatant removed. The residual samples were re-dried $\left(70^{\circ} \mathrm{C}\right)$ and encapsulated for $\mathrm{C}$ and $\mathrm{N}$ analysis using a Thermo Delta $\mathrm{V}$ Conflo III coupled to a Costech 4010 at the UH Hilo Analytical Laboratory, USA. The $\mathrm{C}$ and $\% \mathrm{~N}$ was calculated for the bulk (pre-acidified) samples.

For Iron and phosphorus concentrations, $0.50 \mathrm{mg}$ dry weight (DW) of each powdered leaf were digested in $6 \mathrm{ml} \mathrm{HNO}_{3}$ and $2 \mathrm{ml}$ of $\mathrm{H}_{2} \mathrm{O}_{2}$ following Spalla et al. (2009), and $200 \mathrm{mg}$ of sediment were digested in $6 \mathrm{ml}$ of $\mathrm{HNO}_{3}$ and $2 \mathrm{ml}$ of $\mathrm{HCL}$ following the EPA method 3052 (Kingston and Walter, 1995). The samples were let to cool then diluted with Mili-Q water to be subsequently analyzed by Inductively Coupled Plasma-Optical Emission Spectrometry (Varian Inc. model 720-ES). Analyses of replicates (two replicates between each 20 sample with total of 10) and reference materials (e.g., BBOT and Sulfanilamide in the leaves, NIST 8704 in the sediment for N and C; and Inorganic Ventures and PerkinElmer's Pure Plus for $\mathrm{P}$ and $\mathrm{Fe}$ in the leaves and sediment) were carried out to ensure reproducibility of the results. Then, mean $( \pm \mathrm{SE})$ of nutrient concentration (g DW $\mathrm{Kg}^{-1}$ ) and accumulated stock per unit area (i.e., cumulative mass; $\mathrm{Kg} \mathrm{m}^{-2}$ ) in the top $30 \mathrm{~cm}$ of the sediment was estimated from the four locations.

The nutrient content in $\mathrm{mg} \mathrm{leaf}^{-1}$ was calculated as the product of the nutrient concentration in $\mathrm{mg} \mathrm{g} \mathrm{DW}^{-1}$ and the total dry mass in $\mathrm{g} \mathrm{DW} \mathrm{leaf}^{-1}$ of the leaves Lin and Wang (2001; Figure 2). We also calculated the nutrient resorption after Lin and Wang (2001) and Lovelock et al. (2004), as the ratio between the difference in average nutrient content in $\mathrm{mg} \mathrm{leaf}^{-1}$ from a fully developed or mature leaf and that of senescing leaves, free of grazing damage, and reported this as a percent. Leaf age was estimated using the plastochrone interval approach, i.e., the time in between development of a new node supporting a new leaf pair (Erickson and Michelini, 1957; Duarte et al., 1994; Coulter et al., 2001). Avicennia marina produced 9.59 nodes year $^{-1}$, resulting in an estimated plastochron interval of PI $=38$ days (Almahasheer et al., 2016c), the time interval between production of two consecutive leaf pairs along a branch.

\section{Estimating Nutrient Fluxes With Leaf Loss}

To calculate the leaf export flux of nutrients in senescing leaves in $\mathrm{mg}$ element $\mathrm{m}^{-2}$ year ${ }^{-1}$, we multiplied the mean nutrient content of each element in the senescing leaves with leaves produced $\mathrm{m}^{-2}$ year ${ }^{-1}$. We simply estimated number of leaves produced $\mathrm{m}^{-2}$ year $^{-1}$ after Coulter et al. (2001), which is the product of the number of meristems $\mathrm{m}^{-2}$ multiplied by the number of internodes produced per meristem per year multiplied by two which is the number of leaves per meristem (Figure 2). Specifically, (1) we used a line transect of $3 \mathrm{~m}$ wide by $5-15 \mathrm{~m}$ long in two locations ( $n=74$ trees for Khor Alkharar and $n=153$ tree
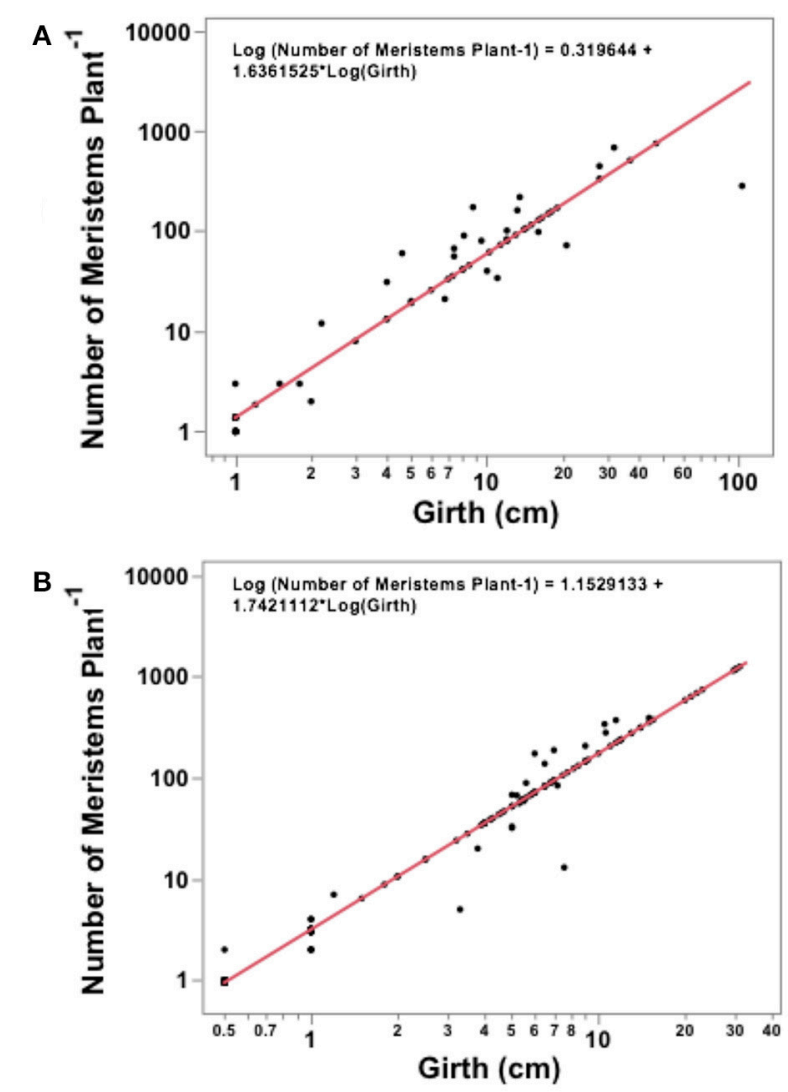

FIGURE 3 | Regression analysis for the Avicenna marina girth and total number of meristems produced in (A) Khor Alkharar and (B) Thuwal Island. 
TABLE 2 | (A) Mean ( \pm SE) for nutrients concentration ( $\mathrm{mg} \mathrm{g} \mathrm{DW}^{-1}$ ), nutrients content (mg leaf ${ }^{-1}$ ) and (B) nutrients resorption (\%) in Avicennia marina leaves from four different locations in the Central Red Sea, and the results (F-ratio) from ANOVA and Tukey HSD post hoc tests for differences in nutrient concentrations among locations.

\begin{tabular}{|c|c|c|c|c|c|c|c|c|}
\hline & Location & & Khor Alkharar & Petro Rabigh & Economic City & Thuwal Island & Average for Central Red Sea & F Ratio (Location) \\
\hline \multirow[t]{9}{*}{ (A) } & Leaf nutrient & No. Rows & 15 & 27 & 30 & 19 & 91 & \\
\hline & & C & $443.8 \pm 4.2^{a}$ & $434.4 \pm 2^{a}$ & $425.2 \pm 2.1^{b}$ & $440.1 \pm 3.4^{a}$ & $434.1 \pm 1.5$ & $9.2^{\star \star}$ \\
\hline & & $\mathrm{N}$ & $10.6 \pm 0.9^{a b}$ & $13.5 \pm 1.1^{\mathrm{a}}$ & $10.7 \pm 0.7^{a b}$ & $9.4 \pm 0.6^{b}$ & $11.2 \pm 0.5$ & $4.1^{\star \star}$ \\
\hline & & $P$ & $0.6 \pm 0.1^{a}$ & $0.8 \pm 0.1^{a}$ & $0.7 \pm 0.1^{a}$ & $0.7 \pm 0.1^{a}$ & $0.7 \pm 0.04$ & $1.6^{\mathrm{ns}}$ \\
\hline & & $\mathrm{Fe}$ & $0.3 \pm 0^{b}$ & $0.6 \pm 0.1^{a}$ & $0.5 \pm 0.1^{a}$ & $0.4 \pm 0.03^{a b}$ & $0.5 \pm 0.03$ & $4.3^{\star \star}$ \\
\hline & $\begin{array}{l}\text { Leaf nutrient } \\
\text { content (mg }\end{array}$ & C & $81.7 \pm 9.3^{a}$ & $98.3 \pm 9.2^{a}$ & $113.2 \pm 11.7^{a}$ & $93.4 \pm 12.1^{a}$ & $99.4 \pm 5.6$ & $1.2^{\mathrm{ns}}$ \\
\hline & leaf $^{-1}$ ) & $N$ & $2 \pm 0.3^{a}$ & $2.9 \pm 0.3^{a}$ & $2.7 \pm 0.3^{a}$ & $1.9 \pm 0.3^{a}$ & $2.4 \pm 0.2$ & $2.1^{\mathrm{ns}}$ \\
\hline & & $\mathrm{P}$ & $0.1 \pm 0.01^{a}$ & $0.1 \pm 0.01^{a}$ & $0.2 \pm 0.02^{a}$ & $0.1 \pm 0.02^{a}$ & $0.1 \pm 0.01$ & $1.4^{\mathrm{ns}}$ \\
\hline & & $\mathrm{Fe}$ & $0.04 \pm 0.01^{b}$ & $0.1 \pm 0.02^{a}$ & $0.12 \pm 0.01^{a}$ & $0.09 \pm 0.01^{a b}$ & $0.1 \pm 0.01$ & $5^{\star \star}$ \\
\hline \multirow[t]{4}{*}{ (B) } & $\begin{array}{l}\text { Leaf nutrient } \\
\text { resorption (\%) }\end{array}$ & No. Rows & 2 & 3 & 3 & 2 & 10 & \\
\hline & & $\mathrm{N}$ & $72 \pm 1$ & $65 \pm 13$ & $69 \pm 8$ & $73 \pm 1$ & $69 \pm 4$ & $0.1^{\mathrm{ns}}$ \\
\hline & & $\mathrm{P}$ & $70 \pm 2$ & $71 \pm 4$ & $74 \pm 5$ & $75 \pm 5$ & $72 \pm 2$ & $0.3^{\text {ns }}$ \\
\hline & & $\mathrm{Fe}$ & $37 \pm 13$ & $38 \pm 11$ & $47 \pm 9$ & 46.6 & $42 \pm 5$ & $0.5^{\mathrm{ns}}$ \\
\hline
\end{tabular}

${ }^{*}=0.05>P>0.01 .{ }^{* *}=P<0.01$. Locations sharing the same superscript letters do not differ among themselves for a particular element.

for Thuwal Island, Table 1) to measure each tree/ seedling girth and number of meristems, then used as regression analysis to get the total number of meristems in the two locations (Figure 3). Then (2) we used the number of internodes year ${ }^{-1}$ for the same two locations above that were obtained from (Almahasheer et al., 2016c) (9.56 node year ${ }^{-1}$ for Khor Alkharrar and 9.72 year $^{-1}$ for Thuwal Island), and multiplied by 2 which is number of leaves per node, following Duke and Pinzon (1992) as the rates of annual node production $=$ half of leaf production.

Statistical analyses, including descriptive statistics, linear regression analyses of leaf age vs. element, general linear models to test differences among stands, and Tukey HSD posthoc test to assess pairwise differences were carried out using JMP, a computer program for statistics developed by the SAS Institute.

\section{RESULTS}

\section{Leaf Production and Nutrient Concentration}

The number of meristems in Avicennia marina trees increased with tree girth both in Khor Alkharar and Thuwal Island $\left(R^{2}\right.$ $=0.95, F=1350, P<0.0001$; and $R^{2}=0.98, F=8809$ and $P<0.0001$, respectively; Figures 3A,B). When combined with tree density, girth distribution and previous estimates of nodes production (Table 1), these relationships allowed to estimate that Avicennia marina in Khor Alkharar produced 7871.5 leaves $\mathrm{m}^{-2}$ year $^{-1}$ and the stand in Thuwal Island produced 7345.2 leaves $\mathrm{m}^{-2}$ year ${ }^{-1}$, which, provided the life span of Avicennia marina leaves is $\leq 1$ year, is equivalent to the leaf litter fall fluxes, as grazing losses were minimal.

The average leaf nitrogen concentration in $\mathrm{mg} \mathrm{N} \mathrm{g} \mathrm{DW}^{-1}$ tended to be low and was significantly higher in Petro Rabigh compared to the other mangrove stands, where average leaf nitrogen content did not differ significantly among these locations (Table 2A). Similarly, the average leaf phosphorous concentration was also low (Table 2A). Leaf $\mathrm{P}$ concentration and content did not vary significantly among stands (Table 2A). Likewise, the average leaf iron concentration was very low (Table 2), and both the average leaf iron concentration and content were higher in Petro Rabigh and Economic City compared to Khor Alkharar, while Thuwal Island showed intermediate values (Table 2A).

The nitrogen and phosphorous concentration in the leaves declined with leaf age as a result of either or both the dilution or leaching of nutrients as the leaves mature and expand (Figure 4). However, iron concentration was stable or tended to increase with leave age (Figure 4). The leaf nutrient content was highly variable between trees, with a general trend to decline in leaves around 200 days old in most of the trees suggesting a retrieval of nutrients from old leaves before these are shed (Figure 5). The trends in elemental concentration and content with leaf age were described, based on regression analysis (Tables S1, S2 and Figures S1, S2). The leaf P: Fe ratio declined sharply with leaf age from 20 in young leaves to around 3 in mature 200 days old then a ratio of 1 in senescing leaves, similarly, $\mathrm{N}$ : Fe also declined sharply from values of $>1,000$ to 100 in mature leaves of 200 days old then 50 in senescing leaves. Contrary, the leaf N: P ratio showed a general trend to increase from values of 30 in young leaves to around 40 at mature leaves of 200 days old and remained the same in senescing leaves (Figure 6).

$\mathrm{N}$ and $\mathrm{P}$ resorption was detected in all sampled trees, whereas Fe resorption was not detected in one out of the 10 trees (Table 2B). There was no significant difference in resorption efficiency between locations for either N, P, or Fe (Table 2B). 


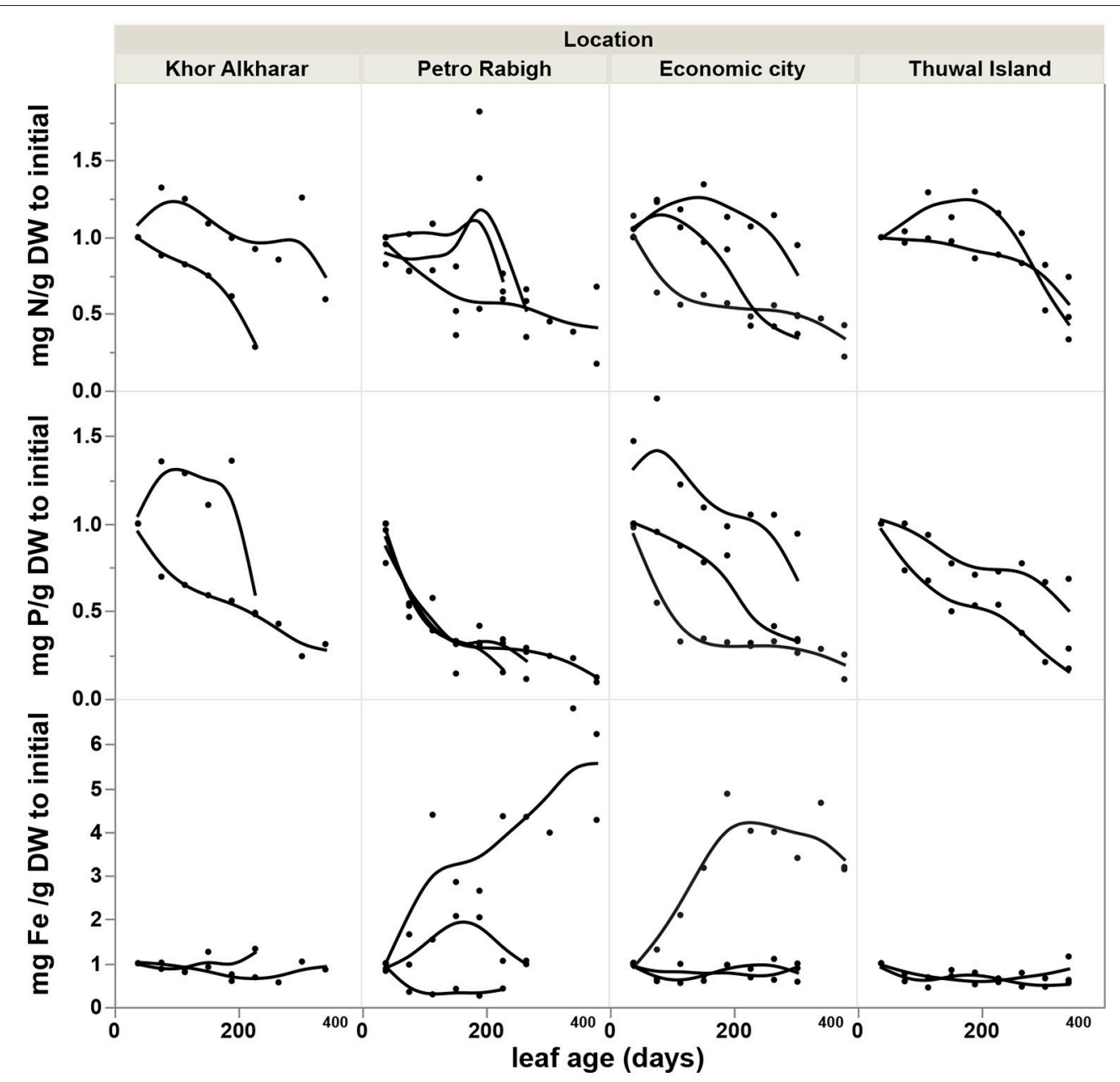

FIGURE 4 | Accumulation rate of nutrients concentration (Difference in $\mathrm{mg} \mathrm{g} \mathrm{DW}^{-1}$ to the value of the first leaf) with the age of Avicennia marina leaves in the Central Red Sea, each smoothed line present one tree branch in a tree.

Hence, we calculated the grand mean $( \pm \mathrm{SE})$ of resorption to be $69 \pm 4 \%$ N, $72 \pm 2 \% \mathrm{P}$ and $42 \pm 5 \% \mathrm{Fe}$, with Fe having lower resorption efficiency compared to $\mathrm{N}$ and $\mathrm{P}$. Resorption efficiency was independent of the maximum nutrient concentration and, therefore, independent of the nutrient status of the plants. However, resorption of $\mathrm{N}$ and $\mathrm{P}$ were significantly correlated $\left(r_{\mathrm{N}-\mathrm{P}}=0.8, P=0.004\right)$, whereas that of Fe with either $\mathrm{N}$ or $\mathrm{P}$ was not significant $\left(r_{\mathrm{Fe}-\mathrm{P}}=0.6, P=0.08 ; r_{\mathrm{N}-\mathrm{Fe}}=0.4, P\right.$ $=0.29$ ). Moreover, leaf stoichiometry (1918 C:36 N:1 P: $0.5 \mathrm{Fe}$ for all leaves, Figure 7) showed a shift from mature leaves (1715 C: $39 \mathrm{~N}: 1 \mathrm{P}: 0.5 \mathrm{Fe})$ to senescing leaves $(4213 \mathrm{C}: 40 \mathrm{~N}: 1 \mathrm{P}: 1.1$ $\mathrm{Fe}$ ) involving a decrease in $\mathrm{N} / \mathrm{Fe}$ and $\mathrm{P} / \mathrm{Fe}$ ratios by half during senescence (Figure 7).

\section{Nutrient Concentration and Accumlated Stock in the Sediment}

Both sediment nutrient concentration in $\mathrm{g} \mathrm{DW} \mathrm{Kg}^{-1}$ and accumulated nutrient stock in sediment $\left(\mathrm{Kg} \mathrm{m}^{-2}\right)$ averaged over the top $30 \mathrm{~cm}$ of sediment did not differ significantly among sites for both nitrogen and phosphorous, whereas the iron sediment concentration was significantly higher in Petro Rabigh, followed by Economic City, Khor Alkharar, and mangroves in Thuwal Island showing the lowest Fe sediment stocks (Table 3).

\section{DISCUSSION}

Avicennia marina in the Central Red Sea was characterized by low nutrient concentrations, as expected from the oligotrophic nature of this ecosystem. The average leaf nitrogen concentration in $\mathrm{mg} \mathrm{N} \mathrm{g} \mathrm{DW}^{-1}$ tended to be low, about half of the levels of $2 \% \mathrm{~N}$ of DW considered to represent nitrogen-sufficient plants, similarly, the average leaf phosphorous concentration was also low, about $1 / 3$ of the $0.2 \% \mathrm{P}$ of $\mathrm{DW}$ considered to represent P-sufficient plants (cf. Almahasheer et al. (2016b). And about half of the concentrations that was found the same species in Kenya of about $20 \mathrm{mg} \mathrm{g} \mathrm{DW}^{-1}$, yet comparable to other species e.g., Xylocarpus granatum, Lumnitzera racemosa, Sonneratia alba in Kenya (Rao et al., 1994). Whereas, leaf nutrient content was 


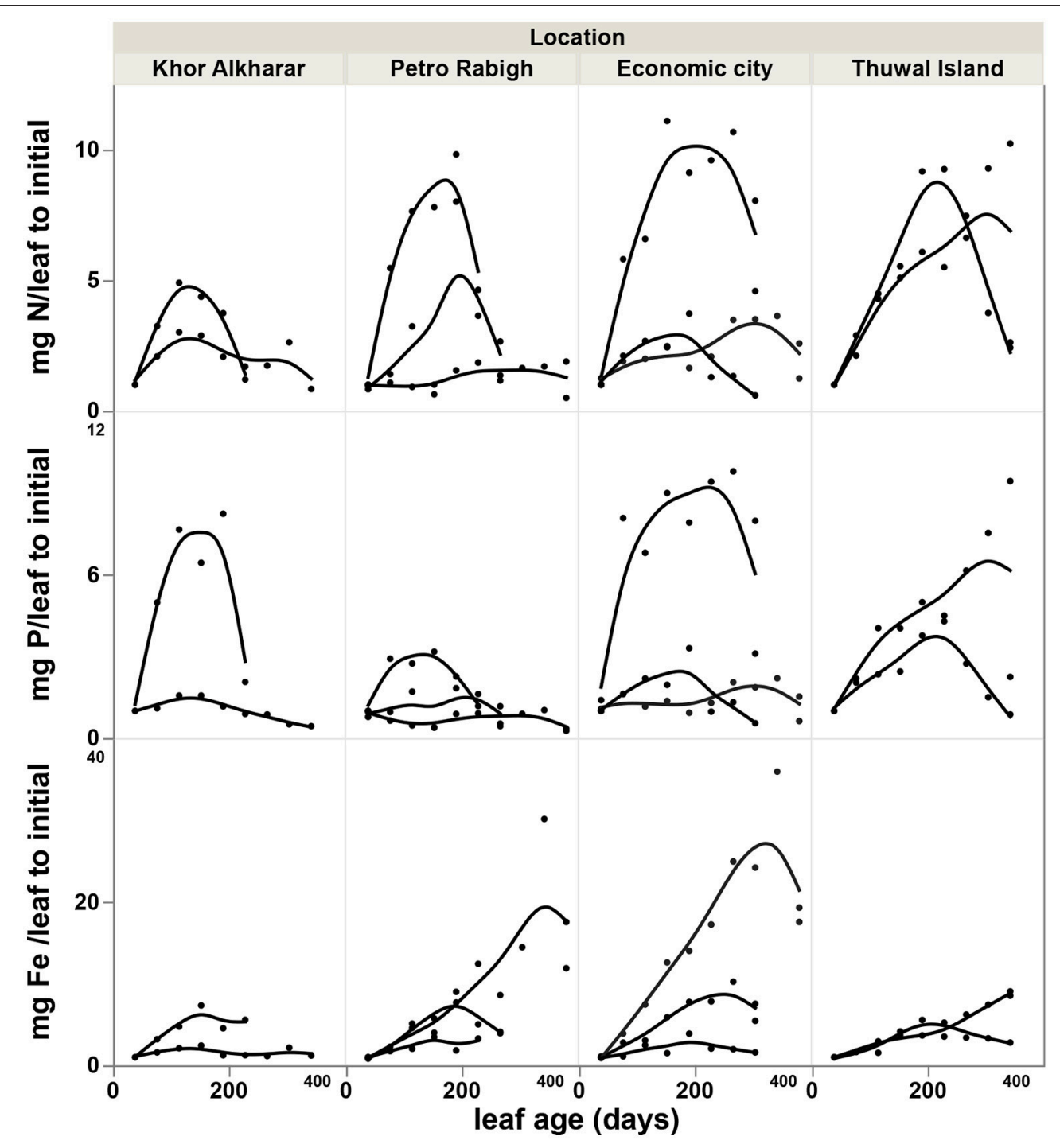

FIGURE 5 | Accumulation rate of nutrients content (difference in $\mathrm{mg} \mathrm{leaf}^{-1}$ relative to the value of the youngest leaf) with age of Avicennia marina leaves in the Central Red Sea, each smoothed line present one tree branch in a tree.

highly variable between sites which could be due to different nutrient inputs. The $\mathrm{N}$ and $\mathrm{P}$ resorption efficiency were in the range of previous estimates of nutrient resorption in Avicennia marina elsewhere (Table 4), which, in turn, are in the higher range of nutrient resorption efficiency reported for aquatic and terrestrial plants (Hemminga et al., 1999; Chapin and Van Cleve, 2000; Reef et al., 2010). However, to the best of our knowledge, iron resorption had not been previously assessed in mangroves. Our results reveal a low iron resorption efficiency $(\leq 42 \%)$ for Avicennia marina in the Central of the Red Sea, about half that for $\mathrm{N}$ and $\mathrm{P}$. The comparatively low efficiency in iron resorption, compared to $\mathrm{N}$ and $\mathrm{P}$ resorption helps explain experimental results reporting that iron additions resulted in significantly taller plants compared with complete fertilizer additions, and consistent with the biogenic nature of the sediments in the Red Sea (Almahasheer et al., 2016b), similar to the iron deficiency of seagrass growing above carbonate sediments reported in the Mexican Caribbean (Duarte et al., 1995). These results also support the findings of a mesocosm experiment (Alongi, 2010) reporting that mangroves growth in some forests may be limited by the rate at which iron is solubilized by iron- reducing bacteria. Particularly when considering the high sediment Fe stock in this study of $1 \mathrm{Kg} \mathrm{m}^{-2}$ compared to around $0.1 \mathrm{Kg} \mathrm{m}^{-2}$ for $\mathrm{N}$ and $\mathrm{P}$ respectively.

The changes in $\mathrm{N}$ and $\mathrm{P}$ concentration with leaf age indicate that there is a dilution effect where an increased leaf mass can be sustained with the same amount of $\mathrm{N}$ and $\mathrm{P}$. However this is not observed with iron, where concentration remains stable or increases, possibly because the concentration of iron is already very low in young leaves and may not be possible to decrease it further and maintain leaf functionality. Aerts and Chapin (1999) proposed that foliar N: P mass ratios $<14$ point at $\mathrm{N}$ limitation, 


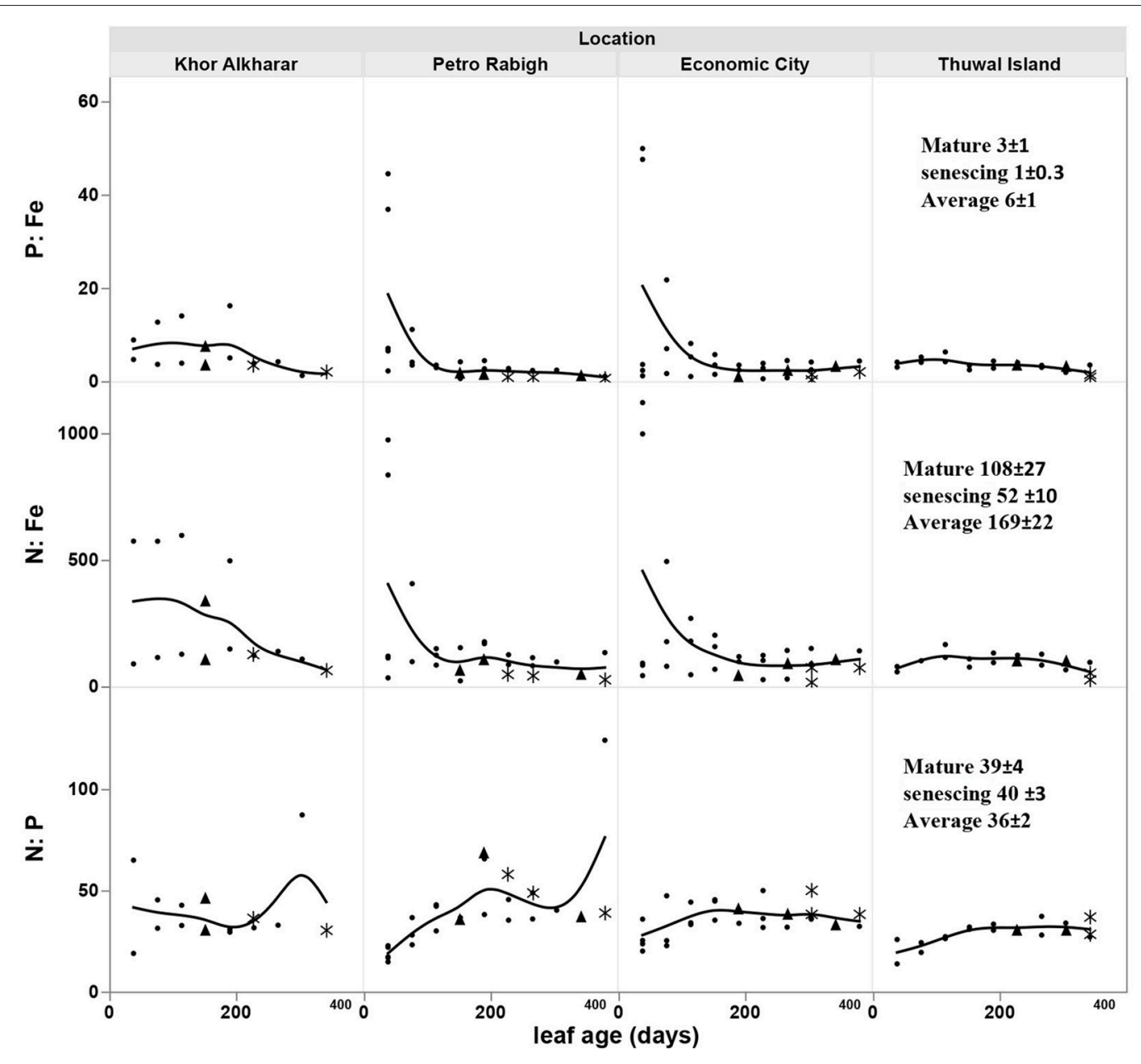

FIGURE 6 | Change in the leaf N: P, N: Fe, and P: Fe ratio with age of Avicennia marina leaves in the Central Red Sea. * for senescing leaves, $\boldsymbol{\Delta}$ for mature leaves. Solid line shows a smoothed line for trees within a location.

whereas foliar ratios $>16$ would indicate $\mathrm{P}$ limitation. This ratio has been used to show $\mathrm{N}$ limitation in Avicennia marina (Wei et al., 2015) and situations where the N:P ratio of mature leaves was higher than the one of young and senescent leaves (Zhou et al., 2010). However, N: P ratios should only be used to diagnose nutrient limitation when factors other than $\mathrm{N}$ or $\mathrm{P}$ are unlikely to be limiting (Güsewell and Koerselman, 2002). Hence, the prevalence of iron limitation in Central Red Sea renders the $\mathrm{N}$ : P ratios of limited diagnostic power. Rather, leaves N: Fe and $\mathrm{P}$ : Fe ratios should be taken in account.

The overall mean of 1918 C: 36 N:1 P: 0.5 Fe in our study revealed nutrient depletion, and was higher than those reported for both plankton $106 \mathrm{C}: 16 \mathrm{~N}: 1 \mathrm{P}$ (Redfield, 1963) and seagrass of 474 C:24 N:1 P (Duarte, 1990), yet, lower than terrestrial plant litter 3007 C:45 N:1 P (McGroddy et al., 2004). Whereas, C: N: $\mathrm{P}$ : Fe ratio in our study of (4213 C:40 N:1 P: 1.1 Fe) in senescing leaves was quite comparable to Avicennia marina senescent leaves in Kenya of 3869 C:52 N:1 P.

Also because of the poor resorption of iron during leaf senescence and the lack of dilution of iron, as opposed to $\mathrm{N}$ and
P, during leaf development, the export flux of senescing leaves contains a high amount of iron of $1 \mathrm{~g} \mathrm{~m}^{-2}$ year $^{-1}$ (Figure 7). Specifically, leaf stoichiometry (1918 C:36 N:1 P: 0.5 Fe for all leaves, Figure 7) showed a shift from mature leaves (1715 C: $39 \mathrm{~N}: 1 \mathrm{P}: 0.5 \mathrm{Fe}$ ) to senescing leaves (4213 C:40 N:1 P: 1.1 Fe) involving a decrease in $\mathrm{N} / \mathrm{Fe}$ and $\mathrm{P} / \mathrm{Fe}$ ratios by half during senescence, indicative of poor resorption of iron during leaf senescence. Hence, the leaf export flux involved a comparatively high amount of $\mathrm{Fe}$ (Figure 7). This points at very high differential iron loss relative to $\mathrm{N}$ and $\mathrm{P}$ with leaf shedding. Therefore, leaf shedding represents a significant source of iron to the Red Sea, an oligotrophic ecosystem without rivers and where the annual budget of nutrients input from the Indian Ocean is considered to be null or even negative (Bethoux, 1988; Souvermezoglou et al., 1989). The leaf export flux of senescing leaves in this study was $813,9,0.4$, and $1 \mathrm{~g} \mathrm{~m}^{-2}$ year $^{-1}$ for C, N, P, and $\mathrm{Fe}$ respectively, which is extremely low when compared to the lower estimate of biomass and nutrients from the Matang Mangroves through leaf litter of about one billion $\mathrm{g} \mathrm{m}^{-2}$ year $^{-1}$ (Gong and Ong, 1990). 


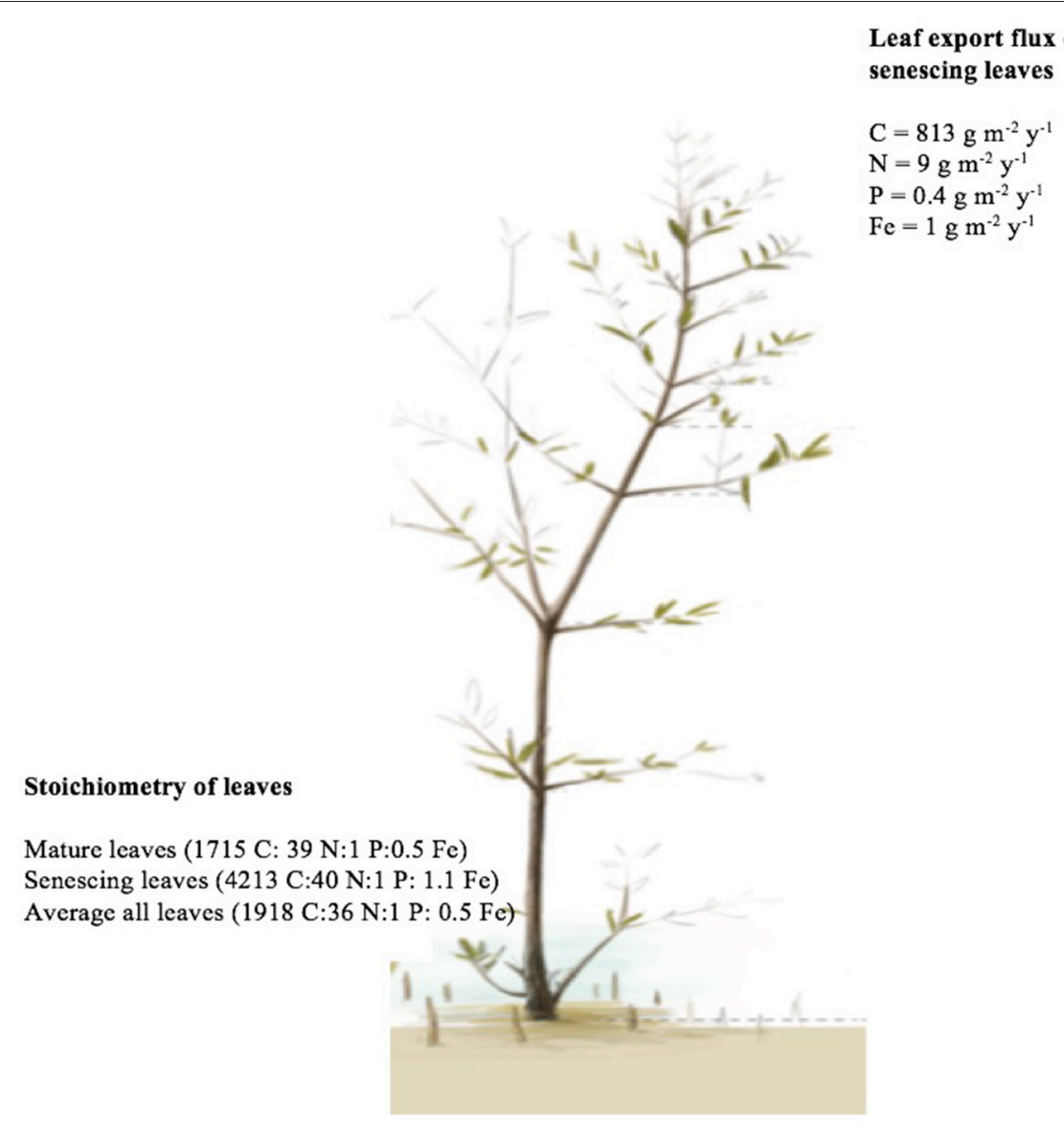

FIGURE 7 | The average nutrient input from senescing leaves in Central Red Sea mangroves and the stoichiometric ratios of the leaf export flux (mature, senescing and average of all ages).

TABLE 3 | Mean ( $(\mathrm{SE})$ of nutrient concentration $\left(\mathrm{g} \mathrm{DW} \mathrm{Kg}^{-1}\right.$ ) and accumulated stock $\left(\mathrm{Kg} \mathrm{m}^{-2}\right)$ in the top $30 \mathrm{~cm}$ of the sediment from four different mangrove locations in the Central Red Sea and the results (F-ratio and results from post-hoc Tukey HSD analysis) from ANOVA to tests for differences between locations.

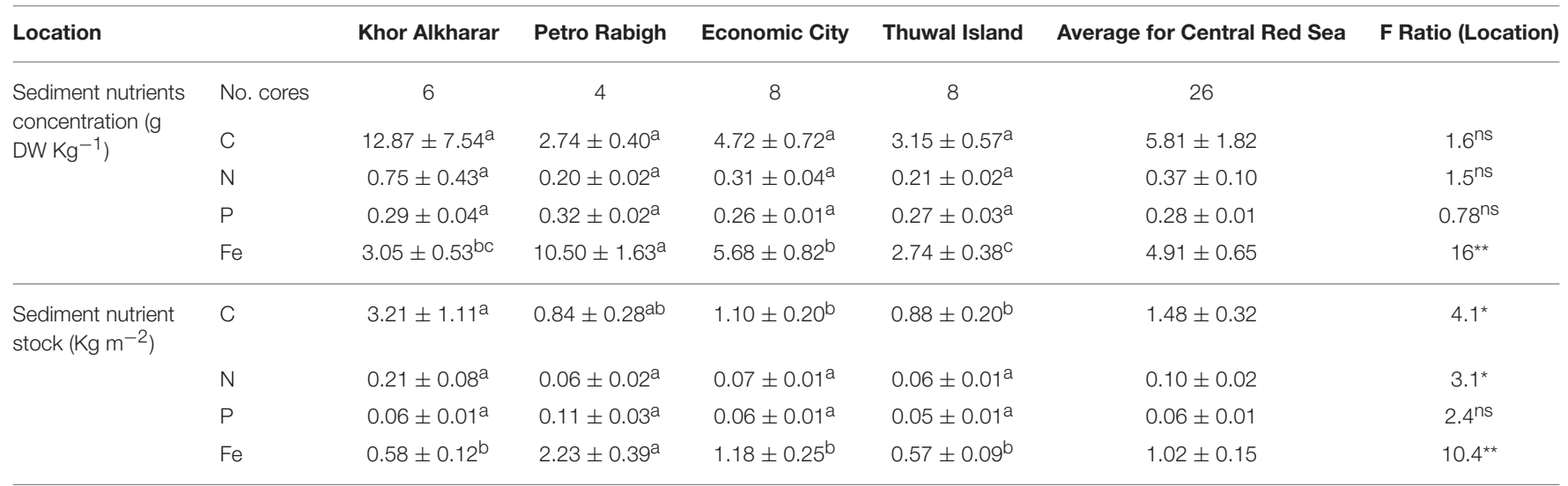

${ }^{\star}=0.05>P>0.01 .{ }^{\star \star}=P<0.01$. Locations sharing the same superscript letters do not differ among themselves for a particular element.

When considering the nutrient export with leaf shedding (Figure 7), extrapolated to the total area covered by mangroves in the Red Sea of around $135 \mathrm{~km}^{2}$ (Almahasheer et al., 2016a), This result in nutrient inputs from mangrove leaf litter (from the senescing leaves) release is 1,214 tons $\mathrm{N}, 59$ tons $\mathrm{P}$ and 120 tons Fe. Although nitrogen fixation rates in Red Sea mangroves have not yet been quantified, nitrogen inputs are likely supported by nitrogen fixation from the atmosphere as the $\delta^{15} \mathrm{~N}$ values in leaves, stems, roots and seeds of Avicennia marain in Central Red Sea were $1.7 \pm 0.2$ 
TABLE 4 | Comparison of nutrients resorption in Avicennia marina leaves from different locations worldwide.

\begin{tabular}{|c|c|c|c|c|}
\hline Location & N-RE (\%) & P-RE (\%) & Fe-RE (\%) & References \\
\hline Kenya & 69 & & & $\begin{array}{l}\text { Rao et al., } \\
1994\end{array}$ \\
\hline Kenya & 68 & 61 & & $\begin{array}{l}\text { Ochieng and } \\
\text { Erftemeijer, } \\
2002\end{array}$ \\
\hline China & 57 to 68 & 49 to 62 & & $\begin{array}{l}\text { Wei et al., } \\
2015\end{array}$ \\
\hline $\begin{array}{l}\text { New Zealand (Veg. } \\
\text { and fertilized) }\end{array}$ & 20 to 60 & 10 to 60 & & $\begin{array}{l}\text { Lovelock } \\
\text { et al., } 2007\end{array}$ \\
\hline Western Australia & 63 to 71 & 43 to 72 & & $\begin{array}{l}\text { Alongi et al., } \\
2005\end{array}$ \\
\hline Western Australia & 19 to 44 & -1 to 60 & & $\begin{array}{l}\text { Lovelock } \\
\text { et al., } 2011\end{array}$ \\
\hline $\begin{array}{l}\text { New Zealand } \\
\text { (Fertilized and } \\
\text { unfertilized) }\end{array}$ & 60 & 60 & & $\begin{array}{l}\text { Lovelock } \\
\text { et al., } 2010\end{array}$ \\
\hline China & 56 & 31 & & $\begin{array}{l}\text { Zhou et al., } \\
2010\end{array}$ \\
\hline Red Sea & 69 & 72 & 42 & Our study \\
\hline
\end{tabular}

(Almahasheer, 2016), indicative of an atmospheric origin of nitrogen.

In summary, our results show that Avicennia marina in the Central Red Sea is able to support a tight nitrogen and phosphorus economy, reflected in the dilution of $\mathrm{N}$ and $\mathrm{P}$ during leaf development followed by high (about 70\%) resorption

\section{REFERENCES}

Aerts, R., and Chapin, F. S. (1999). The mineral nutrition of wild plants revisited: a re-evaluation of processes and patterns. Adv. Ecol. Res. 30, 1-67. doi: 10.1016/S0065-2504(08)60016-1

Almahasheer, H. (2016). Ecosystem Services of Avicennia marina in the Red Sea. Ph.D. Dissertation. King Abdullah University of Science and Technology.

Almahasheer, H., Aljowair, A., Duarte, C. M., and Irigoien, X. (2016a). Decadal stability of Red Sea mangroves. Estuar. Coast. Shelf Sci. 169, 164-172. doi: 10.1016/j.ecss.2015.11.027

Almahasheer, H., Duarte, C. M., and Irigoien, X. (2016b). Nutrient limitation in central Red Sea Mangroves. Front. Mar. Sci. 3:271. doi: 10.3389/fmars.2016.00271

Almahasheer, H., Duarte, C. M., and Irigoien, X. (2016c). Phenology and growth dynamics of Avicennia marina in the Central Red Sea. Sci. Rep. 6:37785. doi: $10.1038 /$ srep37785

Almahasheer, H., Serrano, O., Duarte, C. M., Arias-Ortiz, A., Masque, P., and Irigoien, X. (2017). Low carbon sink capacity of Red Sea mangroves. Sci. Rep. 7:9700. doi: 10.1038/s41598-017-10424-9

Alongi, D. (2002). Present state and future of the world's mangrove forests. Environ. Conserv. 29, 331-349. doi: 10.1017/S0376892902000231

Alongi, D. (2011). Early growth responses of mangroves to different rates of nitrogen and phosphorus supply. J. Exp. Mar. Biol. Ecol. 397, 85-93. doi: 10.1016/j.jembe.2010.11.021

Alongi, D., Clough, B., and Robertson, A. (2005). Nutrient-use efficiency in aridzone forests of the mangroves Rhizophora stylosa and Avicennia marina. Aquat. Bot. 82, 121-131. doi: 10.1016/j.aquabot.2005.04.005

Alongi, D. M. (2010). Dissolved iron supply limits early growth of estuarine mangroves. Ecology 91, 3229-3241. doi: 10.1890/09-2142.1 capacity during leaf senescing, and ranged from 50 to $90 \%$ of $\mathrm{N}$ and P from different plant species (Aerts and Chapin, 1999). In contrast, however, iron is continuously supplied during leaf development and resorption efficiency is poor. As a result, the plants experience differentially high $\mathrm{Fe}$, compared to $\mathrm{N}$ and $\mathrm{P}$, losses, with leaf litter produced by mangroves representing a main source of bioavailable Fe for the Red Sea ecosystem.

\section{AUTHOR CONTRIBUTIONS}

$\mathrm{HA}, \mathrm{CD}$, and $\mathrm{XI}$ designed the study, and carried out the field measurements. HA did the analytical measurements. All authors contributed to the statistical analysis and writing of the manuscript.

\section{ACKNOWLEDGMENTS}

The research reported in this paper was supported by King Abdullah University of Science and Technology through the baseline funding to $\mathrm{XI}$ and $\mathrm{CD}$. We thank staff at the Coastal and Marine Resources core lab in KAUST, as well as Amr Gusti, Red Sea Research Centre, for help in the field, and Vijayalaxmi Dasari for sediment analyses.

\section{SUPPLEMENTARY MATERIAL}

The Supplementary Material for this article can be found online at: https://www.frontiersin.org/articles/10.3389/fmars. 2018.00204/full\#supplementary-material

Bethoux, J. (1988). Red Sea geochemical budgets and exchanges with the Indian Ocean. Mar. Chem. 24, 83-92. doi: 10.1016/0304-4203(88)90007-2

Boto, K. K., and Wellington, J. J. (1983). Phosphorus and nitrogen nutritional status of a northern Australian mangrove forest. Mar. Ecol. Progr. Ser. 11, 63-69.

Chapin, F. S. III. and Van Cleve, K. (2000). "Approaches to studying nutrient uptake, use and loss in plants," in Plant Physiological Ecology, eds R. W. Pearcy, J. R. Ehleringer, H. A. Mooney, and P. W. Rundel (Dordrecht: Springer), 185-207.

Coulter, S. C., Duarte, C. M., Tuan, M. S., Tri, N. H., Ha, H. T., Giang, L. H., et al. (2001). Retrospective estimates of net leaf production in Kandelia candel mangrove forests. Mar. Ecol. Prog. Ser. 221, 117-124. doi: 10.3354/meps. 221117

DOGAN, A., YALCIN, E., SÜRMEN, B., and KUTBAY, H. G. (2015). Seasonal and altitudinal changes in leaf nutrient concentrations of Hedera helix L.(Araliaceae). Revue D'Écologie 70. Available Online at: http://hdl.handle.net/ 2042/56427

Duarte, C. M. (1990). Seagrass nutrient content. Mar. Ecol. Progr. Ser. Oldendorf 6, 201-207. doi: 10.3354/meps067201

Duarte, C. M., Marba, N., Agawin, N., Cebrian, J., Enriquez, S., Fortes, M. D., et al. (1994). Reconstruction of seagrass dynamics: age determinations and associated tools for the seagrass ecologist. Mar. Ecol. Prog. Ser. 107, 195-209. doi: 10.3354/meps 107195

Duarte, C. M., Martín, M., and Margarita, G. (1995). Evidence of iron deficiency in seagrasses growing above carbonate sediments. Limnol. Oceanogr. 40, 1153-1158. doi: 10.4319/lo.1995.40.6.1153

Duke, N. C., and Pinzon, Z. S. M. (1992). Aging Rhizophora seedlings from leaf scar nodes: a technique for studying recruitment and growth in mangrove forests. Biotropica 24, 173-186. doi: 10.2307/2388671 
Erickson, R. O., and Michelini, F. J. (1957). The plastochron index. Am. J. Bot. 297-305. doi: 10.1002/j.1537-2197.1957.tb10544.x

Feller, I. C. (1995). Effects of nutrient enrichment on growth and herbivory of dwarf red mangrove (Rhizophora mangle). Ecol. Monogr. 65, 477-505. doi: 10.2307/2963499

Feller, I. C., McKee, K. L., Whigham, D. F., and O’Neill, J. P. (2003a). Nitrogen vs. phosphorus limitation across an ecotonal gradient in a mangrove forest. Biogeochemistry 62, 145-175. doi: 10.1023/A:1021166010892

Feller, I. C., Whigham, D. F., McKee, K. L., and Lovelock, C. E. (2003b). Nitrogen limitation of growth and nutrient dynamics in a disturbed mangrove forest, Indian River Lagoon, Florida. Oecologia 134, 405-414. doi: $10.1007 / \mathrm{s} 00442-002-1117-\mathrm{z}$

Feller, I. C., Whigham, D. F., O'Neill, J. P., and McKee, K. L. (1999). Effects of nutrient enrichment on within-stand cycling in a mangrove forest. Ecology 80, 2193-2205. doi: 10.1890/0012-9658(1999)080[2193:EONEOW]2.0.CO;2

Gong, W.-K., and Ong, J.-E. (1990). Plant biomass and nutrient flux in a managed mangrove forest in Malaysia. Estuar. Coast. Shelf Sci. 31, 519-530. doi: 10.1016/0272-7714(90)90010-O

Güsewell, S., and Koerselman, W. (2002). Variation in nitrogen and phosphorus concentrations of wetland plants. Perspect. Plant Ecol. Evol. Syst. 5, 37-61. doi: 10.1078/1433-8319-0000022

Hemminga, M. A., Marba, N., and Stapel, J. (1999). Leaf nutrient resorption, leaf lifespan and the retention of nutrients in seagrass systems. Aquat. Bot. 65, 141-158. doi: 10.1016/S0304-3770(99)00037-6

Hussain, S. A., and Badola, R. (2008). Valuing mangrove ecosystem services: linking nutrient retention function of mangrove forests to enhanced agroecosystem production. Wetlands Ecol. Manage. 16, 441-450. doi: $10.1007 / \mathrm{s} 11273-008-9080-\mathrm{z}$

Killingbeck, K. T. (1996). Nutrients in senesced leaves: keys to the search for potential resorption and resorption proficiency. Ecology 77, 1716-1727. doi: $10.2307 / 2265777$

Kingston, H., and Walter, P. (1995). Microwave assisted acid digestion of siliceous and organically based matrices. EPA Draft Method 3052. Available Online at: https://www.epa.gov/sites/production/files/2015-12/documents/3052.pdf

Koch, M. S., and Snedaker, S. C. (1997). Factors influencing Rhizophora mangle L. seedling development in Everglades carbonate soils. Aquat. Bot. 59, 87-98.

Lin, P., and Wang, W.-Q. (2001). Changes in the leaf composition, leaf mass and leaf area during leaf senescence in three species of mangroves. Ecol. Eng. 16, 415-424. doi: 10.1016/S0925-8574(00)00126-9

Lovelock, C. E., Ball, M. C., Martin, K. C., and Feller, I. C. (2009). Nutrient enrichment increases mortality of mangroves. PLoS ONE 4:5600. doi: 10.1371/journal.pone. 0005600

Lovelock, C. E., Feller, I. C., Adame, M. F., Reef, R., Penrose, H. M., Wei, L., et al. (2011). Intense storms and the delivery of materials that relieve nutrient limitations in mangroves of an arid zone estuary. Funct. Plant Biol. 38, 514-522. doi: 10.1071/FP11027

Lovelock, C. E., Feller, I. C., Ball, M. C., Engelbrecht, B. M., and Ewe, M. L. (2006). Differences in plant function in phosphorus-and nitrogen-limited mangrove ecosystems. New Phytol. 172, 514-522. doi: 10.1111/j.1469-8137.2006.01851.x

Lovelock, C. E., Feller, I. C., Ellis, J., Schwarz, A. M., Hancock, N., Nichols, P., et al. (2007). Mangrove growth in New Zealand estuaries: the role of nutrient enrichment at sites with contrasting rates of sedimentation. Oecologia 153, 633-641. doi: 10.1007/s00442-007-0750-y

Lovelock, C. E., Sorrell, B. K., Hancock, N., Hua, Q., and Swales, A. (2010). Mangrove Forest and soil development on a rapidly accreting shore in New Zealand. Ecosystems 13, 437-451. doi: 10.1007/s10021-010-9329-2

Lovelock, C., Feller, I. C., McKee, K., Engelbrecht, B., and Ball, M. (2004). The effect of nutrient enrichment on growth, photosynthesis and hydraulic conductance of dwarf mangroves in Panama. Funct. Ecol. 18, 25-33. doi: 10.1046/j.0269-8463.2004.00805.x

Mandura, A. (1997). A mangrove stand under sewage pollution stress: Red Sea. Mangroves Salt Marshes 1, 255-262. doi: 10.1023/A:1009927605517

McGroddy, M. E., Daufresne, T., and Hedin, L. O. (2004). Scaling of C: N: P stoichiometry in forests worldwide: implications of terrestrial Redfield-type ratios. Ecology 85, 2390-2401. doi: 10.1890/03-0351

McKee, K. L. (1995). Interspecific variation in growth, biomass partitioning, and defensive characteristics of neotropical mangrove seedlings: response to light and nutrient availability. Am. J. Bot. 299-307. doi: 10.1002/j.1537-2197.1995.tb12634.x
Naidoo, G. (1987). Effects of salinity and nitrogen on growth and water relations in the mangrove, Avicennia marina (Forsk.) Vierh. New Phytol. 107, 317-325. doi: 10.1111/j.1469-8137.1987.tb00183.x

Naidoo, G. (2009). Differential effects of nitrogen and phosphorus enrichment on growth of dwarf Avicennia marina mangroves. Aquat. Bot. 90, 184-190. doi: 10.1016/j.aquabot.2008.10.001

Ochieng, C. A., and Erftemeijer, P. L. (2002). Phenology, litterfall and nutrient resorption in Avicennia marina (Forssk.) Vierh in Gazi Bay, Kenya. Trees 16, 167-171. doi: 10.1007/s00468-001-0146-2

Raitsos, D. E., Pradhan, Y., Brewin, R. J., Stenchikov, G., and Hoteit, I. (2013). Remote sensing the phytoplankton seasonal succession of the Red Sea. PLoS ONE 8:e64909. doi: 10.1371/journal.pone.0064909

Rao, R., Woitchik, A., Goeyens, L., Van Riet, A., Kazungu, J., and Dehairs, F. (1994). Carbon, nitrogen contents and stable carbon isotope abundance in mangrove leaves from an east African coastal lagoon (Kenya). Aquat. Bot. 47, 175-183. doi: 10.1016/0304-3770(94)90012-4

Redfield, A. C. (1963). The influence of organisms on the composition of sea-water. Sea 2, 26-77.

Reef, R., Feller, I. C., and Lovelock, C. E. (2010). Nutrition of mangroves. Tree Physiol. 30, 1148-1160. doi: 10.1093/treephys/tpq048

Sato, G., Negassi, S., and Tahiri, A. Z. (2011). The only elements required by plants that are deficient in seawater are nitrogen, phosphorous and iron. Cytotechnology 63, 201-204. doi: 10.1007/s10616-011-9342-0

Souvermezoglou, E., Metzl, N., and Poisson, A. (1989). Red Sea budgets of salinity, nutrients and carbon calculated in the strait of Bab-ElMandab during the summer and winter seasons. J. Mar. Res. 47, 441-456. doi: $10.1357 / 002224089785076244$

Spalla, S., Baffi, C., Barbante, C., Turretta, C., Cozzi, G., Beone, G., et al. (2009). Determination of rare earth elements in tomato plants by inductively coupled plasma mass spectrometry techniques. Rapid Commun. Mass Spectrometry 23, 3285-3292. doi: $10.1002 / \mathrm{rcm} .4244$

Thompson, L. R., Field, C., Romanuk, T., Ngugi, D., Siam, R., Dorry, H., et al. (2013). Patterns of ecological specialization among microbial populations in the Red Sea and diverse oligotrophic marine environments. Ecol. Evol. 3, 1780-1797. doi: 10.1002/ece3.593

Twilley, R. R., and Day, J. (1999). The productivity and nutrient cycling of mangrove ecosystem. Ecosistemas de manglar en América Tropical. Instituto de Ecología, AC México, UICN/ORMA, Costa Rica, NOAA/NMFS, Silver Spring, MD, EUA. 127-151.

Wei, S. D., Liu, X. W., Zhang, L. H., Chen, H., Zhang, H., Zhou, H. C., et al. (2015). Seasonal changes of nutrient levels and nutrient resorption in Avicennia marina leaves in Yingluo Bay, China. South. For. 77, 237-242. doi: $10.2989 / 20702620.2015 .1048420$

Wright, I. J., and Westoby, M. (2003). Nutrient concentration, resorption and lifespan: leaf traits of Australian sclerophyll species. Funct. Ecol. 17, 10-19. doi: 10.1046/j.1365-2435.2003. 00694.x

Zhou, H.-C., Wei, S.-D., Zeng, Q., Zhang, L.-H., Tam, N. F.-Y., and Lin, Y.-M. (2010). Nutrient and caloric dynamics in Avicennia marina leaves at different developmental and decay stages in Zhangiiang River Estuary, China. Estuar. Coast. Shelf Sci. 87, 21-26. doi: 10.1016/j.ecss. 2009.12.005

Zimmermann, C. F., Keefe, C. W., and Bashe, J. (1997). Method 440.0: Determination of Carbon and Nitrogen in Sediments and Particulates of Estuarine/Coastal Waters Using Elemental Analysis. United States Environmental Protection Agency, Office of Research and Development, National Exposure Research Laboratory.

Conflict of Interest Statement: The authors declare that the research was conducted in the absence of any commercial or financial relationships that could be construed as a potential conflict of interest.

Copyright (c) 2018 Almahasheer, Duarte and Irigoien. This is an open-access article distributed under the terms of the Creative Commons Attribution License (CC $B Y)$. The use, distribution or reproduction in other forums is permitted, provided the original author(s) and the copyright owner are credited and that the original publication in this journal is cited, in accordance with accepted academic practice. No use, distribution or reproduction is permitted which does not comply with these terms. 